\title{
Genetic Parameters of Common Wheat in Nepal
}

\author{
Bal Krishna Joshi ${ }^{1 *}$, Dhruba Bahadur Thapa ${ }^{2}$ and Madan Raj Bhatta ${ }^{1}$ \\ ${ }^{1}$ National Agriculture Genetic Resources Center, Khumaltar- Kathmandu \\ ${ }^{2}$ Agriculture Botany Division, Khumaltar- Kathmandu \\ *Corresponding author: joshibalak@yahoo.com
}

Received April 2015; Revised May 2015; Accepted May 2015

Scientific Editor: KH Ghimire

Copyright (C) 2015 NARC. Permits unrestricted use, distribution, and reproduction in any medium, provided the original work is properly cited.

\begin{abstract}
Knowledge on variation within traits and their genetics are prerequisites in crop improvement program. Thus, in present paper we aimed to estimate genetic and environmental indices of common wheat genotypes. For the purpose, eight quantitative traits were measured from 30 wheat genotypes, which were in randomized complete block design with 3 replicates. Components of variance and covariance were estimated along with heritability, genetic gain, realized heritability, coheritability and correlated response. Differences between phenotypic and genotypic variances in heading days, maturity days and plant height were not large. Grain yield and plant height showed the highest phenotypic (18.189\%) and genotypic (12.06\%) coefficient of variances, respectively. Phenotypic covariance was higher than genotypic and environmental covariance in most of the traits. The highest heritability and realized heritability were of heading days followed by maturity days. Genetic gain for plant height was the highest. Co-heritability of 1000-grain weight with tillers number was the highest. The highest correlated response was expressed by grain yield with tillers number. This study indicates the possibility of improving wheat genotypes through selection utilizing existing variation in these traits.
\end{abstract}

Key words: Covariance components, genetic parameters, Triticum aestivum, variance components

\section{सारांश}

बालीको जातीय विकासको लागि बंशाणुगत गुणहरुको विविधता र यी गुणहरुको अनुबंश बारे अध्ययन गर्नु आवश्यक हुन्छ । बंशाणुगत गुणहरु बारे विभिन्न आठ वटा गुणहरुको ३० वटा गहुँको जातहरुमा आर.सी.बि.डी. प्रयोग गरि तीन छुट्टाछुट्टै सेटमा बंशाणुगत गुणहरुको मात्रा जस्तै genetic gain, heritability, coheritability, variance-covariance components आदिको अध्ययन गरिएको थियो । फूल फुल्ने अबधि, पाक्ने अबधि र वोटको उचाईमा phenotypic/genotypic विविधता बीच धैरै फरक नभएको पाइयो। सबै भन्दा बढी phenotypic coefficient of variance (१६.१६\%) गहुँको दानाको तौलमा र genotypic coefficient of variance (१२.०६\%) बिरुवाको उचाईमा पाइयो । अधिकतर गुणहरुमा genotypic / environmental covariances भन्दा phenotypic covariance बढी भएको देखियो । फुल फुल्ने र पाक्ने अवधि जस्ता गुणहरुको heritability र realized heritability सबै भन्दा बढी पाइयो। सबै भन्दा बढ़ी आनुवंशिक उपलब्धि बालीको उचाईमा थियो। हजार दानाको तौल, tiller संख्या संगको coheritability सबै भन्दा बढ़ी थियो । बढ़ correlated response दानाको तौल र tiller संख्याले देखायो । यस अध्ययन बाट उक्त जातहरुमा आनुवंशिक विविधता भएको पाइएकोले उक्त जातहरु बाट नयाँ जात निकाल्न सकिने सम्भावना देखिन्छ।

\section{INTRODUCTION}

Varietal richness both in terms of landraces and modern variety including introduced and wild genotypes of wheat is high in Nepal (NARC 1997, Mudwari 1999, Upadhaya and Joshi 2003, Joshi et al 2004, Mudwari et al 2004, Joshi et al 2013). Altitudinal climatic variation and farmers' needs are probably the major attributers for high wheat diversity. Diversity study among quantitative traits and their genetic parameters estimates are prerequisite in wheat breeding program (Desheva and Kyosev 2015, Farshadfar and Estehghari 2014, Farshadfar et al 2013). Use of genetic resources requires their proper and systematic evaluation due to substantial variation of wheat varieties in India (Pathak and Nema 1985), Ethiopia (Belay et al 1993), Nepal (Joshi et al 2004), Iran (Farshadfar and Estehghari 2014), Bulgaria (Desheva and Kyosev 2015) and many other countries. Murty and Arunachalam (1966) stated that genetic drift and selection in different environments could cause greater diversity than geographical distance. Natural selection super-imposed by human under varied agro-climatic, soil and stress environmental conditions have produced marked variability that can be utilized for new varieties improvement and development (Murty and Arunachalam 1966). Currently, such characterization has been more crucial in the context of climate resilient varieties and resistant not only to diseases but also to drought (Desheva and Kyosev 2015, Farshadfar and Estehghari 2014). It should be recognized that improvement in one character as a result of selection for another depends not only on the genotypic and phenotypic correlations, but also on the genotypic and phenotypic variances associated with them (Johnson et al 1955).

Wheat is the third most important crop after rice and maize in Nepal. Different approaches have been employed to increase the productivity of wheat. Genetic improvement is the major technique to develop high yielding including drought tolerance and climate resilient varieties (Farshadfar et al 2013). Estimates of genetic parameters are important to efficiently breed the wheat. Information on genetic parameters is useful to plant breeders in order to design efficient breeding methods for crop improvement program. Considering these gaps, the objective of present study was to measure variance and covariance components, phenotypic and genotypic coefficients of variations, heritability $\left(\mathrm{h}^{2}\right)$, coheritability $\left(\mathrm{ch}^{2}\right)$, realized heritability $\left(\mathrm{rh}^{2}\right)$ correlated response (CRy) and genetic gain $(\Delta \mathrm{G})$, for selected important quantitative traits of wheat.

\section{MATERIALS AND METHODS}

Altogether 30 wheat genotypes (28 advanced lines and two-released cultivars) were evaluated in Initial Evaluation Trial at Agriculture Botany Division (ABD) in Khumaltar, Kathmandu valley in 2008. The ABD is located at 1350 m above the sea level. The climate of the experimental site is warm temperate mid hill agro-ecological condition. Some of these wheat genotypes were received from 
International Maize and Wheat Improvement Center (CIMMYT), Mexico and some were developed by Agriculture Botany Division. Standard agronomical practices were followed using randomized complete block design with three replications. Eight traits namely heading days, maturity days, plant height, tillers number, grains number per spike, grains weight per spike, 1000-grain weight and grain yield were measured based on the descriptors (IBPGR 1985).

Based on these replicated data, variance, covariance components, and coefficients were estimated. Genetic parameters (heritability, genetic advance, genetic gain, selection differential, realized heritability, coheritability and correlated response) were computed. These were estimated following the procedures of Mudwari (1985), Johnson et al (1955), Robinson et al (1949), Burten and De Vane (1953) and Singh and Chaudhary (1985). Data were processed in MS Excel and analyzed in MINITAB and AGROBASE software.

\section{RESULTS}

The highest genetic coefficient of variation (GCV) was recorded for plant height (12.06\%) followed by grain yield (9.92\%), while lowest GCV was observed for headings and maturity days (Table 1). Phenotypic coefficient of variance (PCV) was usually higher than GCV, but the difference was very low (Table 1). The higher GCV and PCV for grain yield were (9.926\% and 18.169\%), plant height (12.06\% and $12.96 \%)$ and tillers number (9.67\% and 14.89\%), respectively. The highest PCV was shown by grain yield (18.169\%) followed by grain weight per spike (17.199\%) (Table 1).

The heritability $\left(\mathrm{h}^{2}\right)$ estimate varied from $16 \%$ for grain weight/spike to $94 \%$ for heading days (Table 2). Moderate to high heritability estimates were found for 1000-grain weight, tillers number, and plant height. The estimate of $\mathrm{h}^{2}$ for grain yield, grain weight/spike and grain number were per spike less. The genetic gain expressed as a percentage of the mean, ranged from 5.185 for maturity days to 23.104 for plant height. Heading days, maturity days, grain number/spike and grain weight per spike had relatively low values (Table 2).

To assess the tendency of various quantitative traits values for genotypic, phenotypic and environmental components, covariance and coheritability of 30 genotypes were determined (Table 3 and 4). Though most of the traits were inherited together, tiller numbers exhibited much higher values of coheritability with grain number per spike and 1000-grain weight. High coheritability was estimated amongst the traits especially grain yield reflected closer association and lesser environmental influence. The changes brought about through indirect selection ie correlated response (CRy) on an associated trait are given in Table 5. The highest CRy value was shown by grain yield with tillers number.

Table 1. Variance components of phenotype, genotype and environment and coefficient of variation with mean of 30 wheat genotypes (Symbols: Vp, Phenotypic variance. Vg, Genotypic variance. Ve, Environmental variance. PCV, Phenotypic coefficient of variation. GCV, Genotypic coefficient of variation)

\begin{tabular}{lllllll}
\hline Trait & Vp & Vg & Ve & PCV, \% & GCV, \% & Mean \\
\hline Heading days & 23.187 & 21.821 & 1.366 & 4.118 & 3.994 & 116.944 \\
Maturity days & 18.017 & 16.355 & 1.662 & 2.773 & 2.642 & 153.078 \\
Plant height, cm & 142.820 & 123.520 & 19.300 & 12.968 & 12.060 & 92.156 \\
Tillers number & 3017.333 & 1274.333 & 1743.000 & 14.891 & 9.677 & 368.878 \\
Grain number/spike & 32.087 & 5.297 & 26.790 & 15.754 & 6.401 & 35.956 \\
Grain wt/spike, g & 0.080 & 0.013 & 0.068 & 17.199 & 6.807 & 1.648 \\
1000-grain wt, g & 21.383 & 10.983 & 10.400 & 10.073 & 7.220 & 45.905 \\
Grain yield, kg/ha & 207297.333 & 61866.333 & 145431 & 18.169 & 9.926 & 2505.871 \\
\hline
\end{tabular}

Table 2. Genetic parameters estimated from 30 wheat genptypes

\begin{tabular}{|c|c|c|c|c|c|}
\hline Trait & Heritability $\left(h^{2}\right)$ & $\begin{array}{l}\text { Realized heritability } \\
\left(\mathrm{rh}^{2}\right)\end{array}$ & $\begin{array}{l}\text { Expected genetic } \\
\text { advance (GA) }\end{array}$ & $\begin{array}{l}\text { Actual Genetic gain } \\
(\Delta \mathbf{G})\end{array}$ & $\begin{array}{l}\text { Selection differential } \\
\text { (S) }\end{array}$ \\
\hline Heading days & 0.941 & 0.941 & 9.335 & 7.983 & 8.482 \\
\hline Maturity days & 0.908 & 0.907 & 7.937 & 5.185 & 5.712 \\
\hline Plant height & 0.865 & 0.864 & 21.292 & 23.104 & 26.714 \\
\hline Tillers number & 0.422 & 0.422 & 47.790 & 12.956 & 30.675 \\
\hline Grain number/spike & 0.165 & 0.165 & 1.926 & 5.357 & 32.453 \\
\hline Grain wt/spike & 0.157 & 0.156 & 0.091 & 5.549 & 35.430 \\
\hline 1000-grain wt & 0.514 & 0.513 & 4.893 & 10.659 & 20.751 \\
\hline Grain yield & 0.298 & 0.298 & 279.914 & 11.170 & 37.428 \\
\hline
\end{tabular}


Table 3. Phenotypic, genotypic and environmental covariance estimated from 30 wheat genotypes

\begin{tabular}{|c|c|c|c|c|c|c|c|c|}
\hline Trait & & 2 & 3 & 4 & 5 & 6 & 7 & Grain yield \\
\hline \multirow{3}{*}{ Heading days } & $\mathrm{P}_{\text {cov }}$ & 16.060 & -13.730 & -26.325 & 0.907 & 0.165 & 0.768 & -108.128 \\
\hline & $\mathrm{G}_{\mathrm{cov}}$ & 15.344 & -13.559 & -16.331 & 0.233 & 0.014 & 0.489 & 2.754 \\
\hline & $E_{\mathrm{cov}}$ & 0.716 & -0.171 & -9.995 & 0.674 & 0.151 & 0.279 & -110.882 \\
\hline \multirow{3}{*}{ Maturity days } & $\mathrm{P}_{\text {cov }}$ & & -18.891 & -47.643 & 5.187 & 0.107 & -0.445 & 144.139 \\
\hline & $\mathrm{G}_{\mathrm{cov}}$ & & -20.395 & -37.831 & 5.458 & 0.124 & 0.313 & 191.899 \\
\hline & $E_{\text {cov }}$ & & 1.504 & -9.812 & -0.270 & -0.017 & -0.759 & -47.760 \\
\hline \multirow{3}{*}{ Plant height } & $\mathrm{P}_{\text {cov }}$ & & & -71.626 & -5.595 & 0.564 & 9.378 & -280.233 \\
\hline & $\mathrm{G}_{\mathrm{cov}}$ & & & -112.209 & -8.617 & 0.383 & 8.745 & -775.469 \\
\hline & $\mathrm{E}_{\mathrm{cov}}$ & & & 40.583 & 3.021 & 0.180 & 0.633 & 495.236 \\
\hline \multirow{3}{*}{ Tillers number } & $\mathrm{P}_{\text {cov }}$ & & & & -21.446 & 2.144 & -4.199 & 13753.840 \\
\hline & $\mathrm{G}_{\mathrm{cov}}$ & & & & -61.458 & -2.100 & -27.371 & 5871.005 \\
\hline & $\mathrm{E}_{\mathrm{cov}}$ & & & & 40.012 & 4.244 & 23.172 & 7882.835 \\
\hline \multirow{3}{*}{ Grain number/spike } & $\mathrm{P}_{\text {cov }}$ & & & & & 1.479 & -4.625 & 273.031 \\
\hline & $\mathrm{G}_{\mathrm{cov}}$ & & & & & -0.063 & -3.368 & 33.298 \\
\hline & $E_{\text {cov }}$ & & & & & 1.542 & -1.257 & 239.733 \\
\hline \multirow{3}{*}{ Grain wt/Spike } & $\mathrm{P}_{\text {cov }}$ & & & & & & 0.485 & 47.818 \\
\hline & $\mathrm{G}_{\mathrm{cov}}$ & & & & & & 0.258 & 14.646 \\
\hline & $E_{\mathrm{cov}}$ & & & & & & 0.227 & 33.172 \\
\hline \multirow{3}{*}{1000 -grain wt } & $\mathrm{P}_{\text {cov }}$ & & & & & & & 189.764 \\
\hline & $\mathrm{G}_{\mathrm{cov}}$ & & & & & & & 312.688 \\
\hline & $E_{\text {cov }}$ & & & & & & & -122.924 \\
\hline
\end{tabular}

Table 4. Coheritability $\left(\mathrm{ch}^{2}\right)$ among quantitative traits in 30 wheat genotypes

\begin{tabular}{|c|c|c|c|c|c|c|c|c|}
\hline Trait & Heading & Maturity & Plant & Tillers & Grain & Grain & 1000-grain & Grain yield \\
\hline Heading days & & 0.955 & 0.988 & 0.620 & 0.257 & 0.087 & 0.637 & -0.025 \\
\hline Maturity days & & & 1.080 & 0.794 & 1.052 & 1.159 & -0.703 & 1.331 \\
\hline Plant height & & & & 1.567 & 1.540 & 0.680 & 0.932 & 2.767 \\
\hline Tillers number & & & & & 2.866 & -0.979 & 6.519 & 0.427 \\
\hline Grain & & & & & & -0.043 & 0.728 & 0.122 \\
\hline Grain wt/spike & & & & & & & 0.532 & 0.306 \\
\hline 1000-grain wt & & & & & & & & 1.648 \\
\hline
\end{tabular}

Table 5. Correlated response (CRy) among quantitative traits in wheat

\begin{tabular}{|c|c|c|c|c|c|c|c|}
\hline Trait & Heading days Maturity & lant heig & lers num & number & $\operatorname{ain} w t / s$ & 0-grain & Grain yield \\
\hline Heading days & 6.564 & -5.800 & -6.986 & 0.099 & 0.006 & 0.209 & 1.178 \\
\hline Maturity days & & -9.898 & -18.360 & 2.649 & 0.060 & 0.152 & 93.131 \\
\hline Plant height & & & -6.022 & -0.462 & 0.021 & 0.469 & -41.616 \\
\hline Tillers number & & & & -2.305 & -0.079 & -1.026 & 220.175 \\
\hline Grain number/spike & & & & & -0.023 & -1.225 & 12.109 \\
\hline Grain wt/spike & & & & & & 1.875 & 106.456 \\
\hline 1000 -grain wt & & & & & & & 139.297 \\
\hline
\end{tabular}

\section{DISCUSSION}

The magnitude of heritable variability, more particularly its genetic component is the most important aspect of the genetic constitution of the breeding material, which has a close bearing on the response to selection. For this determination, it was necessary to divide the total phenotypic variance of the quantitative traits into its components as these are the basis for genetic analysis, because the dimensions of these components decide the breeding behavior of the population and provide the bases of selection techniques (Moghaddam et al 1998). The contribution of environmental factors was substantially important on total variance because of the lower values of GCV in comparison to PCV. Farshadfar and Estehghari (2014), Desheva and Kyosev (2015) also reported similar result. GCV gives a quantitative measurement of genetic variability in a particular trait. The highest genetic coefficient of variation in plant height followed by grain yield indicates the effective selection for these traits. Heading days (3.99\%) and maturity days (2.64\%) exhibited lower values of GCV suggesting that these traits are influenced by environment. Therefore, the selection for these traits will not be effective. Similar results were also obtained by Mudwari (1985). Since, most of these traits are controlled polygenically and inherited quantitatively, thus substantial environmental influence might impact on these traits. Maturity days, heading days, plant height and tillers number were exhibited higher genetic variance than environmental variance (Table 1) indicating thereby a lesser influence of environment upon these traits. These traits had also high heritability values (Table 2). 
High genotypic variance for a particular trait may not reflect heritable proportion of variation. Estimates of variance and its components alone are not helpful in determining the heritable portions of variation (Falconer 1960). For this, an estimation of heritability $\left(\mathrm{h}^{2}\right.$ ), the heritable proportion of variances of the traits seems necessary. High genetic gain was observed for plant height, tillers number, 1000grain weight and grain yield. Similar results were observed by Moghaddam et al (1998) confirming the validity estimates of present results.

In the present study, the estimate of $\mathrm{h}^{2}$ was large for 1000-grain weight (0.514), plant height (0.865), heading days (0.941), low for grain yield (0.298) and grain number (0.165) (Table 2). These values were similar to the findings of Sikka and Jain (1958) showing the validity of the findings. Bhullar et al (1982) in genetic analysis of durum wheat reported low $\mathrm{h}^{2}$ estimates for grain yield, spikes per plant, medium for spikelets per spike, grain per spike, 1000-grain weight and plant height. Heritability estimates reported for grain yield in wheat were usually low (Gandhi et al 1964, Pathak and Nema 1985, Mudwari 1985). High GCV value with intermediate estimates of $\mathrm{h}^{2}$ and genetic gain in this study agreed with Belay et al (1993).

Since environmental variance is dependent upon the conditions of culture or management, more variable (fluctuating) conditions reduce $h^{2}$, contrarily higher uniformity increases it. The values of $h^{2}$ computed in this study for wheat refer to the populations grown in Khumaltar, Kathmandu Valley or similar condition elsewhere to great extent. However, such values for other populations in other situations could be liable to be more or less similar according to the population and the environmental conditions. The genotypeenvironment interaction variance was not separated from the genetic variance in this study, therefore the estimates of GCV, $\mathrm{h}^{2}$ and genetic gain might be inflated.

Genetic gain along with high $\mathrm{h}^{2}$ is more useful in predicting the resultant effects of selection (Johnson et al 1955). Plant height exhibited the highest genetic gain, whereas tillers number, 1000-grain weight and grain yield showed substantially high response to selection (Table 2). Three characters i.e. plant height, tillers number and 1000-grain weight exhibiting high $\mathrm{h}^{2}$ along with higher genetic gain suggests that these characters can also be improved by selection. The low genetic gain against high $\mathrm{h}^{2}$ estimate for heading days and maturity days showed that the expression of these characters were dependent to non-heritable variability up to certain extent.

The expected genetic advance (GA) was the highest on grain yield, but the highest genetic gain was observed on plant height (Table 2). The gain on grain yield from selection expressed as a percentage of the mean was $11.17 \%$. This means that if the top $5 \%$ of the wheat plants were chosen, the grain yield would be expected to increase by $11.17 \%$ after one cycle of selection.

Grain yield, 1000-grain weight, tillers number and plant height possessed substantially higher genetic variability and also exhibited higher genetic gains revealing greater response to the selection. These observations agreed with the results reported by Belay et al (1993) and Moghaddam et al (1998). A low GCV and low GA were observed for heading days and maturity days (Table 1 and 2). These indicated that the characters were under high environmental influence thus, selection based on these characters would be ineffective. The high value of GCV, $\mathrm{h}^{2}$ and GA estimated for plant height, tillers number and 1000-grain weight indicated the predominance of additive gene action suggesting direct phenotypic selection based on these traits would be effective for varietal improvement.

The $\mathrm{h}^{2}$ and $\mathrm{rh}^{2}$ values were similar in four traits and $\mathrm{rh}^{2}$ was slightly lower than $\mathrm{h}^{2}$ in others four traits (Table 2). The rh${ }^{2}$ is primarily a description of the response and may not provide a valid estimate of the $h^{2}$ in the base population (Falconer, 1960). Larger population tends to give response to selection due to mainly to larger realized $h^{2}$. Days to maturity and 1000-grain weight have played important role to increase grain yield because of high genetic covariance of these traits with grain yield (Table 3). Selection based on the number of tillers and grain number per spike could not be considered effective to increase yield due to high environmental covariance. High genotypic covariance between grain yield and weight was also reported by Farshadfar and Estehghari (2014). High values of genotypic covariance are very useful in breeding program to improve the traits simultaneously. Coheritability estimates were positive for most of traits (Table 4). The high coheritability values of grain yield with maturity days, plant height and 1000-grain weight indicate that selection on these traits would affect largely on grain yield. Farshadfar and Estehghari (2014) observed high coheritability values of grain yield with other agro-morphological traits.

If the trait under selection is genetically correlated with other trait(s), one can expect improvement in the correlated trait(s) as well. Thus, improvement in a trait can be made by direct as well as indirect selection. If we consider a plant height as selection criteria, negative indirect result will be observed in grain yield (Table 5). Because of the linkage relationship, correlated response frequently occurs under selection.

Knowledge of the genetic parameters of a population is useful in designing an effective breeding program. High $\mathrm{h}^{2}$ and GCV (and therefore high genetic advance) are positive indication that the variation in these traits is attributable to a high degree of additive genetic effect. Selection for these characters should be effective and satisfactory for practical purpose. Information on these aspects will be valued by wheat breeders.

\section{ACKNOWLEDGEMENTS}

This study was financially supported by Nepal Agricultural Research Council. Authors expressed sincere thanks to A. Mudwari for technical support and guidance. 


\section{REFERENCES}

Belay G, T Tesema, HC Becker and A Merker. 1993. Variation and interrelationships of agronomic traits in Ethiopian tetrapoloid wheat landraces. Euphytica 71:181-188.

Bhullar GS, R Singh and KS Gill. 1982. Genetic architecture of grain yield and certain other traits in durum wheat. Crop Improve. 9(1):54-59.

Burton GW and EM De Vane. 1953. Estimation of heritability in tall fescue. Agron. J. 45:478-481.

Desheva G and B Kyosev. 2015. Genetic diversity assessment of common winter wheat (Triticum aestivum L.) genotypes Emir. J. Food Agric. 27(3):283-290.

Falconer DS. 1960. Introduction to Quantitative Genetics. Oliver and Boyd, London.

Farshadfar E and MR Estehghari. 2014. Estimation of genetic architecture for agro-morphological characters in common wheat. International Journal of Biosciences 5(6):140-147.

Farshadfar E, F Rafiee and H Hasheminasab. 2013. Evaluation of genetic parameters of agronomic and morpho-physiological indicators of drought tolerance in bread wheat (Triticum aestivum L.) using diallel mating design. Australian Journal of Crop Sciences 7(2):268-275.

Gandhi SM, AK Sanghi, KS Nathawat and MP Bhatnager. 1964. Genotypic variability and correlation coefficient relating to grain yield and a few other quantitative characters in Indian wheats. Indian J. Genet. 24:1-8.

IBPGR. 1985. Descriptors for wheat. IBPGR, Rome, Italy.

Johnson HW, HF Robinson and RF Comstock. 1955. Estimates of genetic and environmental variability in soybean. Agron. J. 47:314318.

Joshi BK, A Mudwari and MR Bhatta. 2013. Wheat gene pool and its conservation in Nepal. Conservation Science 1: 39 -46. http://www.thenaturefoundation.org/consci/index.php/cs/article/view/18

Joshi BK, A Mudwari, MR Bhatta and GO Ferrara. 2004. Genetic diversity in Nepalese wheat cultivars based on agromorphological traits and coefficients of parentage. Nepal Agric. Res. J. 5:7-18.

Moghaddam M, B Endaie and JB Waines. 1998. Genetic variation for and interrelationships among agronomic traits in landraces of bread wheat from southwestern. Iran. J. Genet. Breed. 52:73-81.

Mudwari A, DB Thapa, MR Bhatta, TP Pokhrel, RP Sah, DR Bhandari, B Sharma, L Ghale, AR Lohani, B Bhandari, S Pariyar, GO Ferrara and BK Joshi. 2004. Participatory varietal selection in wheat for identifying farmers preferred variety and disseminating technology faster. In: Agricultural Technologies for Poverty Reduction (YN Ghimire and KR Bhatta, eds). Proc. $7^{\text {th }}$ National Outreach Research Workshop, 24-25 June 2004 NARC, Kathmandu. Pp.171-184.

Mudwari A. 1985. Studies on genetic variability, path analysis and selection indices on some biometric characters in rainfed wheat (Triticum aestivum L.). MSc Thesis, Rajasthan College of Agriculture, Udaipur, India.

Mudwari A. 1999. Wild relatives of wheat and its status in Nepal. In: Wild Relatives of Cultivated Plants in Nepal (R Shrestha and B Shrestha, eds). Proc. National Conf. 2-4 June 1999, Kathmandu. Pp.83-89.

Murty BK and V Arunachalam. 1966. The nature of divergence in relation to breeding system in some crop plants. Indian J Genet. 26A:131-145.

NARC. 1997. 25 Years of Wheat Research in Nepal (1992-1997). NARC, NWRP, Nepal.

Pathak NN and DP Nema. 1985. Genetic advance in landraces of wheat. Indian J. Agric. Sci. 55: 478-479.

Robinson HF, RF Comstock and PH Harvey. 1949. Estimates of heritability and degree of dominance in corn. Agron J. 41:353-359.

Sikka SM and KBL Jain. 1958. Correlation studies and application of discriminant function in aestivum wheats for varietal selection under rainfed conditions. Indian J. Genet. 18:178-186.

Singh RK and BD Chaudhary. 1996. Biometrical methods in quantitative genetic analysis. Kalyani Publishers, India.

Upadhaya MP and BK Joshi. 2003. Plant genetic resources in SAARC countries: Their conservation and management. Nepal chapter. SAARC Agriculture Information Center. Pp.297-422. 